\title{
Articles
}

\section{Vultures revered in time and place}

\author{
Dieter Haas ${ }^{1}$ and Peter Mundy ${ }^{2}$
}

\begin{abstract}
${ }^{1}$ Geierschutzinitiative GESI, Zillhausestr. 36, D 72459 Albstadt, Germany.dghaas@web.de
${ }^{2}$ Department of Forest Resources and Wildlife Management, National University of Science and Technology, Bulawayo, Zimbabwe. mundy@gatorzw.com
\end{abstract}

One of the conundrums of humanity and its evolution is a belief in gods or a God, and in a life hereafter. When did these beliefs appear in history, and why? Were they subsequent to the Agricultural Revolution and settled humans with their domesticating plants and animals, or were they in consciousness before 10,000 YBP, in Stone Age hunter-gatherer people? The latter is certainly suggested by what we have gleaned from the South African San (Bushmen) (Mundy et al. 1992: ch.8). By the time humans were recording their beliefs and thoughts in tangible form, whether as rock art, engravings, hieroglyphics, or whatever, vultures were there!

In fact we should expect vultures to be there. They are scavengers, ready to eat any large-enough dead animal, even a human. In addition, a belief in an afterworld and an after-life must surely wonder how we get there - and what better method than a bird carrying us up to the heavens. (But what part of us?). So it is no surprise that vultures feature with humans, as porters, in myths, and perhaps even as divinities.

In Hindu mythology, all birds of prey descend from the ancient Garuda. 
By means of legend it was transformed to

a semi-divine being. The holy Indian

vulture Jatayu knows everything of the past and the future because it has flown across the whole world. It fights against monsters. It is kind to herds and gods. In the great Indian epic Ramayana the vulture-saint Jatayu loses his life during a long air fight against the ten-headed Ravana, the demon king of Lanka, now Sri Lanka. Jatayu is trying to rescue Sita, the wife of Lord Rama, and Ravana manages to cut off one of Jatayu's wings, and escapes with Sita (See also Naoroji 2006:
The Bearded Vulture Gypaetus barbatus with its impressive size and markings, and playful fantastic flight acrobatics in the windy updrafts of the mountains, is the paragon for the creation of these myths. It was believed to be both an eagle and a vulture, and was accurately described in one of the oldest Vedas or holy scriptures of the Indians, around 1,000 BC. In different epics of the Vedas, this Bearded Vulture is dedicated to the gods of the sky.

28).

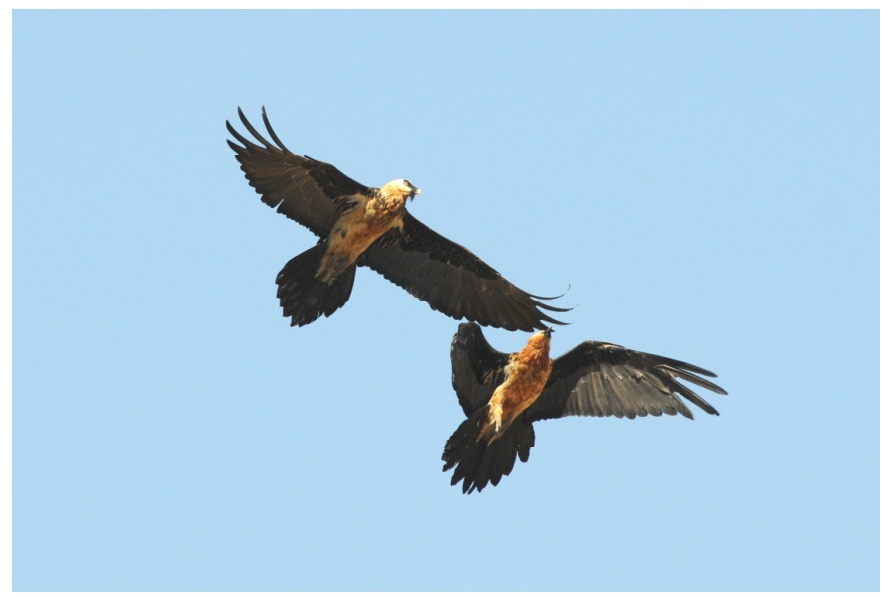

Figure 1. The Bearded Vulture is the paragon of the holy Indian vulture Jatayu. Here are two birds of the African race meridionalis, 19 December 2010, Robe, Ethiopia. Photo: D. Haas. 
The language of these old texts is Sanskrit. Thus the Egyptian Vulture Neophron percnopterus is called Bhasak and Goshtkukut (Naoroji 2006: 28) which relate to its commensalism with humans in their towns and villages. Its presence at these settlements is presumably welcomed, because it indicates prosperity and welfare, and it symbolises the surveillance and protection of the herds of domestic animals.

In Oriental religions, humans are consistently seen as a part of nature, not apart from nature. So the disposal of human corpses is consigned to the vulture community in certain localities of India and Tibet, as it was in the past in Persia (now Iran), Anatolia in Turkey, and in south-eastern Europe. This means of disposal, by feathered undertakers, has been documented many times (e.g. Anon. 1982, Laycock 1985, Houston 1990, Satheesan 1998).

Perhaps the Parsi religious community is a particularly well-known example of this, and especially now as the absence of vultures is threatening their funerary method (Harding 2001, Reddall 2006, Naoroji 2006: 73). Parsis are followers of the religion founded by the prophet Zarathustra (Greek: Zoroaster) in around 1,000 B.C., originally in Persia, and now known as Zoroastrianism. It is a form of monotheism. It teaches that the world is the site of a cosmic battle that is continually raging between good and evil. Eventually the good god Ahura Mazda will defeat the powers of evil (McWhirter 1995). The four elements of earth, water, air and fire are sacred to the Parsis, and must not be polluted. Therefore human cadavers are laid out to be disposed of naturally, i.e. by scavengers, in specially built towers.

It's said that Parsis left Persia in A.D. 717 (Temple 1914: 306) because of intolerance from the new religion of Islam as practised by the Mohammedans. Many of them settled in India by the $10^{\text {th }}$ century (McWhirter 1995), and when the 
intrepid traveller Peter Mundy arrived in India in 1628 (departing in 1634) he wrote that "Parsees are only found about Suratt" (Temple 1914). Surat is situated on the Gulf of Khambhat at $250 \mathrm{~km}$ north of Mumbai; Parsis now live mainly around Mumbai. In 1633 Mundy drew a diagram of one of the towers at Surat, here reproduced as Figure. 2. We presume this is the first notification of a tower to the western world. Nowadays it is called a "Tower of Silence" or Dokhma or Dakhma (Temple 1914, Ludwig 1984, Naoroji 2006: 73). Mundy described the situation thus (we have changed his text into modern English spelling (Temple 1914: 305-306):

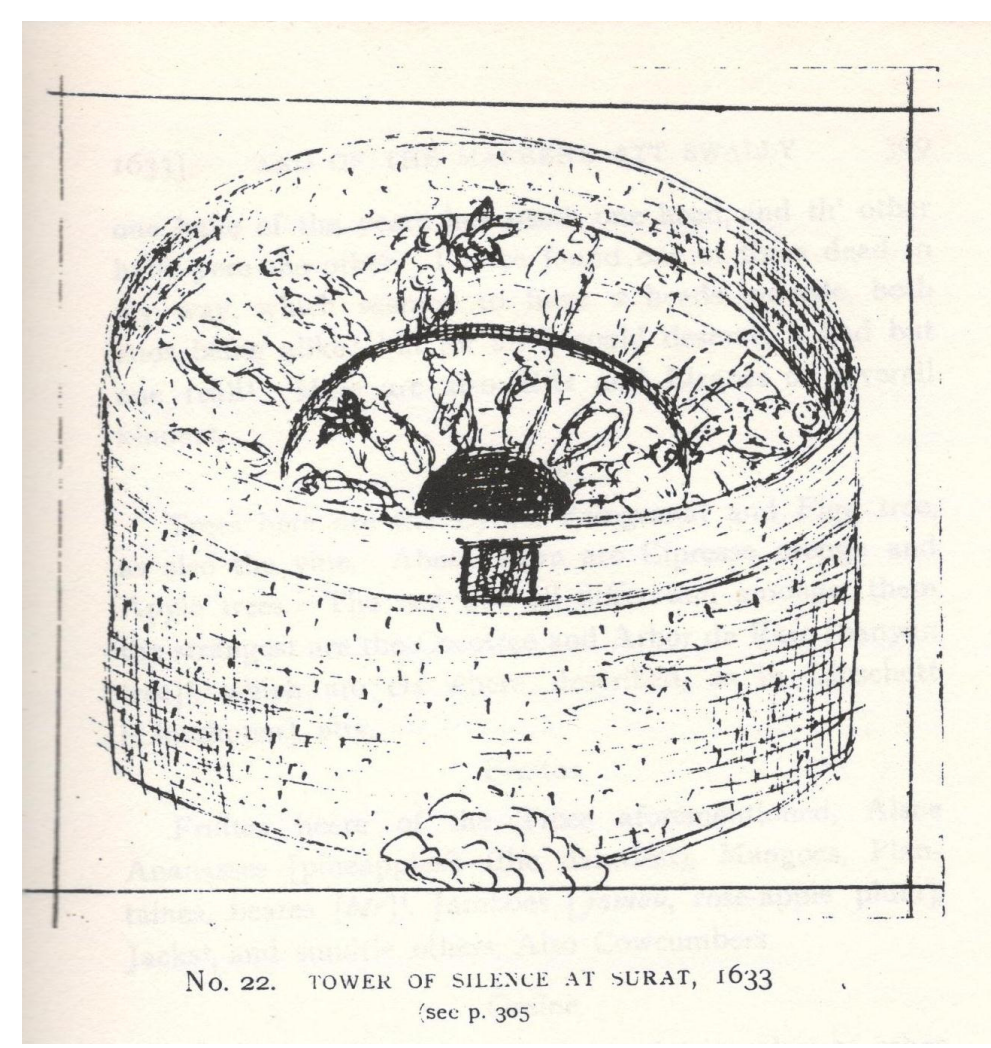

Figure 2. A drawing of a Tower of Silence by Peter Mundy in 1633. 
"Parsees who neither bury nor burn their dead, but in certain round, wide, low towers they are laid on their backs with some covering over them circularwise, beginning at the circumference until it come round, and within them another rank, they lie to putrefy, or to be eaten by fowl. Their bones are thrown into a deep concavity like a well, made in the centre of it, as per this figure [i.e. our Figure 2], I having been in one of them myself. If any by chance touch any part of a dead man, as a bone etc., he presently rends all his clothes in pieces and burns them, remaining as unclean for 3 days, none coming near him. It is also held a great misfortune if their fire should go out in their house, and procured again with a great deal of ceremony. These people came first out of Persia, leaving their country because they would not leave their religion at the coming up of Mahometisme [sic], and these are also those that manure [cultivate, Temple 1914] the Toddy Trees at Saratt, etc."

The bird species, which enabled this very hygienic and easy recycling even of human dead bodies, was mainly the Oriental White-backed Vulture Pseudogyps bengalensis in India and Iran (Figs. 3 and 4), in Tibet the Himalayan Griffon Gyps himalayensis and the Bearded Vulture.

In Mumbai human corpses were/are laid out in seven such "Towers of Silence" in the middle of a once large park-like wooded area that is visited by relatives for mourning and editation. However, more and more high-rise buildings are encircling the park on Malabar Hill, Mumbai. Back to the 1950s, Rishad Naoroji remembers a "resident breeding group" of Oriental Whitebacked Vultures in the "sanctuary", two or three active nests to every large tree (Naoroji 2006: Bearded Vulture. 73)! That surely means hundreds of nests. In Ludwig's (1984) main photograph of part of the perimeter wall of one tower, there 


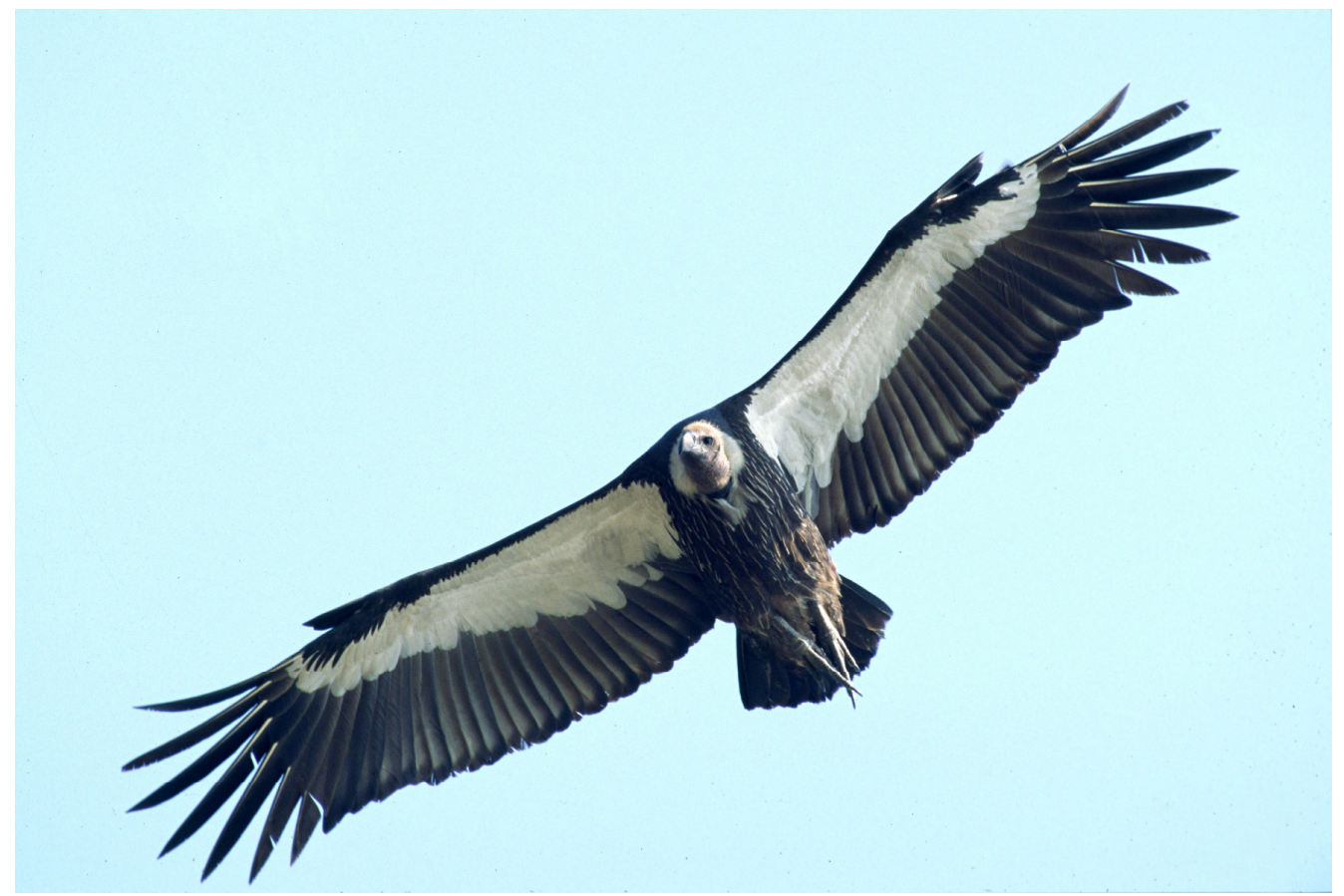

Figure 3. Adult Oriental White-backed Vulture, 28 January 1997, north of Delhi, India. Photo:

D. Haas.

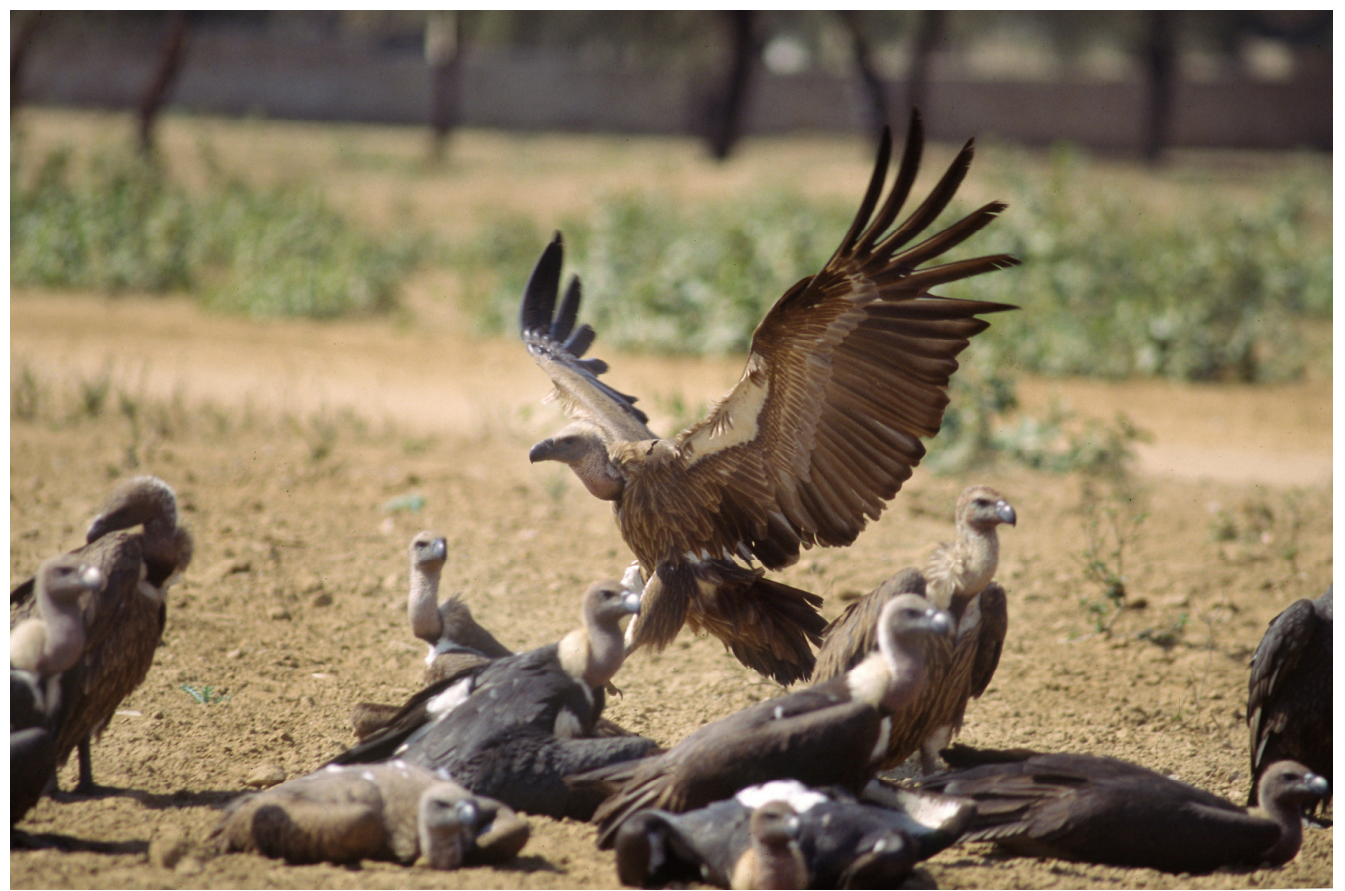

Figure 4. K.F. Gauggel and D. Haas, on an India tour in 1997, were concerned about groups of

Oriental White-backed Vultures in the fields, apparently weakened, with empty crops. The disastrous decline of the species accelerated after that date. At the time, it was a mystery for them. 20 January 1997, south of Jaipur, India. Photo: D. Haas. 
are 76 vultures perched thereon, almost all of them adults. Today no vultures breed there, nor do any even visit, declines having been noticed in the 1980s (Naoroji 2006: 73-74). Curiously, Rishad Naoroji notes that the near-absence of the birds at the towers in the 1990s predates the infamous collapse throughout the subcontinent. Other methods of disposing of human bodies have been proposed recently, with the warning that diclofenac is also used by humans as medication.

Meantime in Iran, the last Shah (Mohammed Reza Pahlavi, reigned 194179) had forbidden this form of funeral rite. This seems to have been in response to a perceived decline of vultures in that country, though more recently no concern has been expressed for the birds (Mansoori 2002, Eliotout 2007). Twentyfive thousand Parsis still live in Iran (Wikipedia encyclopaedia) and one wonders what they can do with their human dead in that Islamic republic?
In Anatolia (Turkey) excavations

have shown corpses laid out perhaps to be consumed by vultures, even 8,000 years ago. The remaining bones were then kept in shrines on which such procedures were depicted. It is thought that funerals using vultures also occurred in south-eastern Europe.

For the ancient Egyptians in the times of the Pharaohs, five thousand years ago to about 330 B.C., vultures were revered more so than in any other culture. The religion was polytheistic and sun-worshipping, and two goddesses were represented by vultures, Nekhbet by the Lappet-faced Vulture Torgos tracheliotos and Mut by the Eurasian Griffon Gyps fulvus (Mundy et al. 1992: ch. 8). The people believed that all vultures were female, hence symbolic of maternal love and protection, and that they were fertilised by the east wind. Many paintings of these species appear on frescoes. Tutankhamun (reigned $c$. 1328-1322 BC, dying at the age of about 
18 years, McWhirter 1995) wore a necklace on which hung "surely the most beautiful and truthful rendering of a Lappet-faced Vulture" (Houlihan 1986:42) as a pectoral made of solid gold. Also his funeral mask sported the heads of the vulture and the cobra side by side. One can barely imagine the thrill when Tutankhamun's tomb was discovered in 1922 with these and other artefacts intact. We have previously explained the significance of the juxtaposed vulture and cobra (Mundy et al. 1992: 337-339).

In Greek mythology vultures are connected to the war-god Ares, and thus affiliated to war. This might well have its origin in past experiences on military confrontations. Herodotus (c. 484-423 B.C.) considered the vulture to be a friend of Hercules. Being a historian of wars, Herodotus was probably familiar with vultures on battlefields, and perhaps he thought that Hercules needed the help of a vulture during his Labours.
In Roman mythology either twelve or six vultures were said to have shown the brothers Romulus and Remus where to found Rome, in 753 B.C. according to legend, and on seven hills! A vulture is said to have predicted, somehow, the reigns of Romulus, Julius Caesar (60-44 B.C.) and Augustus Caesar (from 27 B.C.). The ancient Roman coat of arms, preceding every legion and no doubt feared for centuries, is adorned not only with SPQR (Senatus Populusque Romanus) but also with a large hookbilled bird in 'spread-eagle' motif. This was usually taken to be the Golden Eagle Aquila chrysaetos, but could it in fact be the Cinereous Vulture Aegypius monachus (J.-P. Choisy pers. comm.) ? The size of the bill suggests the latter. While the vulture has been extinct in Italy for many years (Bijleveld 1974), presumably it was common enough two thousand and more years ago. 
The so-called voracity of vultures (meaning the Eurasian Griffon) was proverbial in former times. The bird was even said to perceive death approaching (in Europe). One has to smile - over the past centuries there have been so many battlefields and wars across Europe that the continent must surely have been a veritable 'restaurant' for vultures, and hardly any need therefore for perception! Maybe the same could be said in other continents too. In southern Africa vultures are believed to be clairvoyant and to know where a dead animal is; unfortunately this puts a premium on their brains (Mundy 1990). Back in Europe, impatient heirs to any kind of fortune were and still are called vultures, though this is very derogatory of course to the birds; income tax collectors suffer the same opprobrium. This calumny has survived in Germany (DH pers. obs.) and no doubt in many other places. Ironically it is where these "shining lights of the sun and wise globetrotters" (Haas 2011b) are ruthlessly exterminated that they are so caricatured.

Between us, and over the years, we have had many impressive, close-up and memorable experiences with wild vultures. DH has stood within metres of wild Bearded Vultures, PM has lifted Cape Griffons Gyps coprotheres and Hooded Vultures Necrosyrtes monachus off their nests, as just a few examples. The decrease of many species and loss of their habitats is a warning sign of the destruction of our natural basis of existence, as well as an indication of the decline of creation.

Certainly at least in Germany, DH believes that effective and remedial action is overdue, now that vultures are starting to return. Conservation actions need not conflict with agriculture and hunting, and could offer a stepping-stone for the resettlement of vultures in longabandoned areas. 
In Hungary, for example, where the Hungarians are said to revere the vulture Eurasian Griffon was said to breed until (= Eurasian Griffon) because it rescued a ca 1920, a reintroduction programme is Hungarian princess (Sachse 1981). being attempted in the northeast.

\section{REFERENCES}

Anon. 1982. The feathered undertakers of Tibet [quoting Rampa, T.L., 1956, The third eye]. Vulture News 8: 34-36.

Bijleveld, M. 1974. Birds of prey in Europe. Macmillan, London.

Eliotout, B. 2007. Le vautour fauve. Delachaux et Niestle, Paris.

Haas, D. 2011a. Der Niedergang der Bengalengeier. Apokalypse im Vogelparadies. Vogel 2/11: 46-50.

Haas, D. 2011b. Altweltgeier in der Mythologie und im religiösen Brauchtum. Der Geier als Gott. Vogel 2/11: 52-53.

Harding, L. 2001. Threat to Parsi rite as vultures die. Vulture News 44: 46-47.

Houlihan, P.F. 1986. The birds of ancient Egypt. Aris \& Phillips, Warminster (England).

Houston, D.C. 1990.Use of vultures to dispose of human corpses in India and Tibet, p. 186. In: Newton, I. and Olsen, P., Birds of prey, Merehurst Press, London.

Laycock, H.T. 1985. Vulture reminiscences. Vulture News 14: 27-28.

Ludwig, J. 1984. Ein Fressen für die Geier. Die Bunte 38/1984: 16

Mansoori, J. 2002. The vultures of Iran. Vulture News 47: 39-40.

McWhirter, A. (Ed.) 1995. Illustrated dictionary of essential knowledge. Reader's Digest Association, London. 
Mundy, P.J. 1990. Vultures in African culture, p. 179. In: Newton, I. and Olsen, P., Birds of prey, Merehurst Press, London.

Mundy, P., Butchart, D., Ledger, J. and Piper, S. 1992. The vultures of Africa. Acorn Books and Russell Friedman Books, Randburg and Halfway House (South Africa).

Naoroji, R. 2006. Birds of prey of the Indian subcontinent. Christopher Helm, London.

Reddall, B. 2006. Endangered vultures highlight Parsi culture clash. Vulture News 54: 55-56.

Sachse, E. 1981. A monument to a vulture. Vulture News 6: 26.

Satheesan, S,M. 1998. The role of vultures in the disposal of human corpses in India and Tibet. Vulture News 39: 32-33.

Temple, R.C. (Ed.) 1914. The travels of Peter Mundy, in Europe and Asia, 1608-1667. Vol. II. Travels in Asia, 1628-1634. Hakluyt Society, London. [Kraus Reprint Limited, Nendeln/Liechtenstein, 1967]. 